\title{
The Janus Face of Professional Knowledge: What Organizational Principles Are behind the Students' Perceptions of Professional Knowledge in New Norwegian Teacher Education?
}

\author{
Erik Bratland (iD) and Mohamed El Ghami $(D)$ \\ Faculty of Education and Arts, Nord University, Nesna 8700, Norway \\ Correspondence should be addressed to Mohamed El Ghami; mohamed.el-ghami@nord.no
}

Received 19 October 2021; Revised 8 November 2021; Accepted 9 November 2021; Published 26 November 2021

Academic Editor: Ehsan Namaziandost

Copyright (c) 2021 Erik Bratland and Mohamed El Ghami. This is an open access article distributed under the Creative Commons Attribution License, which permits unrestricted use, distribution, and reproduction in any medium, provided the original work is properly cited.

\begin{abstract}
Integration of theory and practice is the key element in the research on teachers' professional knowledge. Traditionally, this topic has created a polarization between practical and theoretical knowledge. The reform in the new Norwegian teacher education has introduced a new and watered-down concept of knowledge and research-based knowledge in education. With the reform, conflicting perceptions have arisen of what we can understand with professional knowledge in teacher education. Based on Maton's Legitimation Code Theory, and with examples from a study of students' R\&D papers, this paper sheds light on the conflicting concept of professional knowledge in new Norwegian teacher education. The paper refutes a generic concept of knowledge and argues that teachers' professional knowledge is based on practices that are informed by specialized forms of knowledge in the subject area.
\end{abstract}

\section{Introduction}

The reform of Norwegian teacher education, which was initiated in 2017, is associated with a fundamental shift in education policy in Norway in the 2000s. This shift is related to profound societal changes [1], with a transition to a knowledge society $[2,3]$, but can also be more specifically localized to the introduction of international, large-scale surveys in Norwegian schools [4]. The introduction of the large-scale, international surveys (Programme for International Student Assessment [PISA]; Trends in International Mathematics and Science Study [TIMSS]; and Progress in International Reading Literacy Study [PIRILS]), and especially the PISA-test, legitimized a fundamental change in Norwegian education policy [5], with subsequent reforms in Norwegian schools and later in Norwegian teacher education. These changes are part of an international and neoliberal reform wave as discussed in $[6,7]$ and introduce new content in school and teacher education. The new Norwegian teacher education acquired crucial inspiration from
Finland, a country that has achieved high scores in PISA tests in schools $[4,8]$. In the same way as the Finnish model, the new Norwegian five-year teacher education will emphasize scientific and research-based content, to develop a new type of research-based professional knowledge, which will provide a new foundation for teachers' teaching practices in schools. Norwegian and Nordic teacher education has for a long time been dominated by a distinctive Scandinavian version of reform pedagogy [4, 9-11], with major implications for learning and knowledge in education. However, there are indications that the reform in Norwegian teacher education has not weakened the progressive pedagogy, rather it can be argued that this position has been revitalized [12], with the advent of a generic version of what can be understood as professional knowledge in education $[13,14]$. This is a version, where professional knowledge is understood as a particular form of action competence, which is informed by different pedagogical approaches as discussed in [15], regardless of the subject area's form of knowledge. The concept of professional knowledge, as it is expressed in 
the new Norwegian teacher education, appears with a Janus face, in the span between a progressive pedagogy and specialized knowledge in the subject area. With these changes, two different versions of the concept of professional knowledge are developed in $[12,16]$, something that has transformed teacher education into a contested space. In the new Norwegian teacher education, there is a dispute about what is meant by professional knowledge in education, whether it is the subjects' specialized knowledge or generic pedagogical approaches that should form the basis for the student's professional knowledge base in teacher education. This paper examines these tensions in the new Norwegian teacher education, by studying the students' submitted development and research (R\&D) papers at Nord University. This paper argues that professional knowledge is inextricably linked to the subject area, where the subject area's specialized form of knowledge informs the practices, which is crucial if we want to strengthen the basis for teachers' professional practice in school and teacher education.

\section{Literature Review and Theoretical Framework}

2.1. Why Does Knowledge Matter in Teacher Education? In the 2000s, several educational sociologists, with roots in a socially realistic position, have argued that knowledge matters in education $[1,17,18]$. This research can be seen as a reaction to contemporary neoliberal education reforms, and the idea that "knowledge" can be understood as something that arises in a particular context, as a result of mental or social processes in education. This position, which can be associated with pedagogical approaches, is characterized by what Maton [19] (pp. 3-14) has described as a "subjective doxa" and leads to research that focuses on ways of knowing. Pedagogical approaches typically focus on learning processes [15], where knowledge is reduced to knowing, to what is in people's minds [19]. These psychology-informed approaches, which have dominated education research for decades [20], examine learning as generic processes, which are separated from the forms of knowledge being learned. Although this research may shed light on learning processes, the underlying principles of what is being taught and learned in the classroom are absent from this analysis. When knowledge is reduced to knowing, "knowledge" is at best linked to curriculum goals or appears as a kind of pedagogical content knowledge [21], while questions about how the subject area's knowledge shapes teachers' knowledge practices, how cumulative knowledge building can take place, and in what way this specialized knowledge is included in teachers' professional knowledge are left out of this picture. This research reduces knowledge to knowing and leads to a perception that education is only about learning. When education is understood as learning, the research is focused on student-centered learning methods, on interactions in the classroom, and on pupils' perceptions and attitudes, which are analyzed as ways of knowing. When knowledge is reduced to knowing, and not seen as a study object of its own, the question of what is learned, whether the pupils understand the subjects' specialized knowledge, becomes of less importance.

In contrast to typical pedagogical approaches, the mentioned sociologists argue that there are different kinds of knowledge, which will have significant implications for knowledge practices in the classroom. The subjects' different forms of knowledge have effects and will have an impact on knowledge building and teachers' practices in the classroom $[22,23]$. A crucial implication is that pupils in school should have access to the subjects' specialized forms of knowledge, something Young has referred to as "powerful knowledge" [18]. Powerful knowledge is abstract and theoretical knowledge, as it is expressed in the theories and concepts of the disciplines. This knowledge gives students "epistemic access" [24] (p. 140) which is a prerequisite for conceptual progression and cumulative knowledge building in education $[19,25]$. According to Young and Muller [16], students in professional education need access to specialized knowledge, to justify and use practical knowledge in special contexts, but also to anchor professional knowledge in concepts and theories that are context-transcendent, with the development of an increasingly strong degree of generality.

The generic version of professional knowledge, often referred to as the 21st-century form of learning [26, 27], reduces knowledge in education to competence and skillsbased learning, to something that can be extracted from experiences or practices, where "knowledge" can be constructed by students in a particular context. Lack of "epistemic access" has, as mentioned, several consequences in that the role of knowledge in education is obscured, and in the absence of attention to how specialized forms of knowledge in the subject areas are involved in knowledge practices in education. In the paper, these issues will be related to the students " $R \& D$ papers, where the purpose is to uncover students" perceptions of professional knowledge and to investigate what kind of organizational principles are behind the students' perceptions of professional knowledge in new Norwegian teacher education.

2.2. Conceptualization of Professional Knowledge: A Framework Based on Legitimation Code Theory (LCT). This section aims to provide a theoretical framework that illuminates the organizational principles underlying the knowledge practices and that provides a more differentiated insight into the forms of knowledge that characterize teachers' professional knowledge. Where pedagogical approaches focus on learning processes, Maton's Legitimation Code Theory (LCT) introduces a more differentiated framework, which aims to make different forms of knowledge visible in education $[19,22]$. In this paper, we will make use of semantics, a dimension that is suitable for examining the forms of knowledge practices that are expressed in the new teacher education. This approach will be used to examine the forms of knowledge and knowledge practices that are expressed in the students' submitted research and development (R\&D) papers in the new Norwegian five-year teacher education (see Tables 1 and 2). 
TABLE 1: An external language of description for sematic gravity (SG) in student papers.

\begin{tabular}{|c|c|c|c|}
\hline Concept & $\begin{array}{c}\text { Semantic } \\
\text { gravity (SG) }\end{array}$ & Indicators & $\begin{array}{l}\text { Example quotes from empirical data (students' R\&D } \\
\text { papers) }\end{array}$ \\
\hline \multirow{3}{*}{$\begin{array}{l}\text { Context- } \\
\text { dependency }\end{array}$} & SG- & $\begin{array}{l}\text { Theories, concepts, and terms with meanings that } \\
\text { are less dependent on the context, associated with } \\
\text { specialized domains of practices (academic } \\
\text { disciplines, subjects, professions, etc.) }\end{array}$ & $\begin{array}{l}\text { "Inner motivation is affected by various factors: The } \\
\text { sense of mastery, expectations associated with the } \\
\text { outcome, one's beliefs, values and goals" (P11) } \\
\text { "This paper shall investigate whether a specific } \\
\text { external motivation from the teacher's side can be } \\
\text { considered as a factor to increase the pupils learning }\end{array}$ \\
\hline & & & $\begin{array}{l}\text { outcomes" (P10) } \\
\text { "Teacher/student experienced that these pupils }\end{array}$ \\
\hline & SG+ & $\begin{array}{l}\text { Words, terms, and concepts with meanings that are } \\
\text { more dependent on the context, associated with } \\
\text { practices within that context (personal experiences, } \\
\text { opinions about learning, etc.) }\end{array}$ & $\begin{array}{l}\text { learned from each other and that they got marveled } \\
\text { together" (P12) } \\
\text { "The survey I have done has taught me things I } \\
\text { consider to be important in my future profession as } \\
\text { a teacher. The biggest thing I learned is that children } \\
\text { are incredibly good at talking about books" (P13) }\end{array}$ \\
\hline
\end{tabular}

TABLE 2: An external language of description for semantic density (SD) in student papers.

\begin{tabular}{|c|c|c|c|}
\hline Concept & $\begin{array}{c}\text { Sematic } \\
\text { density (SD) }\end{array}$ & Indicators & $\begin{array}{c}\text { Example quotes from empirical data (students' R\&D } \\
\text { papers) }\end{array}$ \\
\hline \multirow{2}{*}{$\begin{array}{l}\text { Content } \\
\text { knowledge }\end{array}$} & $\mathrm{SD}+$ & $\begin{array}{l}\text { Theories, terms, and concepts in subject areas, with } \\
\text { many meanings, apply and are related to practices in } \\
\text { education }\end{array}$ & $\begin{array}{c}\text { "A good understanding of the Periodic Table } \\
\text { contributes to forming the basis for and promoting } \\
\text { progression in the learning of chemistry" (P24) } \\
\text { "Map can be used for visual learning, which helps to } \\
\text { develop students' ability of what is called Higher Order } \\
\text { thinking" (P14) }\end{array}$ \\
\hline & SD- & $\begin{array}{l}\text { Words, terms, and concepts, with fewer meanings, } \\
\text { that tone down subject knowledge, apply and are } \\
\text { related to practices in education }\end{array}$ & $\begin{array}{l}\text { "In the development of social competence, it is } \\
\text { important to establish a learning environment that } \\
\text { stimulates social skills in everyday situations" (P1) } \\
\text { "How can the good conversation strength students' } \\
\text { mastery of experiences?" (P9) }\end{array}$ \\
\hline
\end{tabular}

Semantics is an approach that is suitable for analyzing the organizational principles that underlie students' knowledge practices. Semantics examines discourses and practices and their underlying principles (see Figure 1), which are given by the strength of semantic gravity and semantic density. Maton has defined semantic gravity and semantic density as follows [28] (p.15):

Semantic gravity refers to the degree to which meaning relates to its context. The stronger the semantic (SG+), the more meaning is dependent on its context; the weaker semantic gravity (SG-), the less meaning is dependent on its context.

Similarly, semantic density is defined as follows:

Sematic density refers to the degree of condensation of meaning within practices. The stronger semantic density $(\mathrm{SD}+)$, the more meaning is condensed within practices; the weaker semantic density, the fewer meanings are condensed.

All practices include both semantic gravity and semantic density, but the strength of these relationships will vary (+, $-)$. Semantic gravity refers to the meaning's dependence on the context. The context-dependence of meanings allows an almost infinite grading of strength, where strong semantic gravity (SG+) refers to meanings that largely depend on the context (e.g., about a specific event or experience), while weak semantic gravity refers to more context-independent meanings (e.g., theoretical explanations of the event).

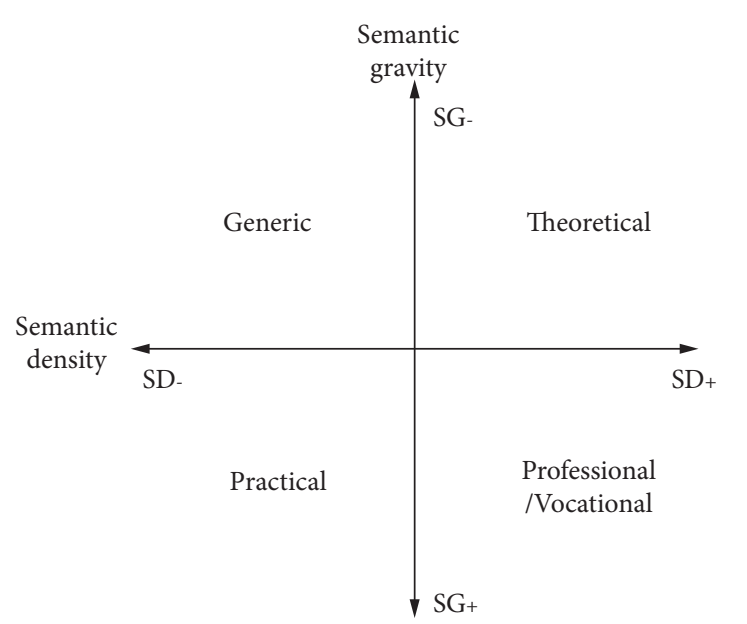

FIGURE 1: Four forms of knowledge, based on the concepts of semantic gravity (SG) and semantic density (SD) (Figure 1 is reproduced from Shay, 2013).

Semantic density refers to the degree of condensation of the meaning of a concept, and the strength can be related to the semantic structure in which it is located. A concept that condenses many meanings will have a relatively strong semantic density (SD+, e.g., social class), while a concept such 
as a classroom will include fewer meanings and therefore have a weaker density (SD-).

An analysis of different curricula, based on Maton's theory [29] (p. 572) differentiates between four different forms of knowledge in the curriculum: theoretical, practical, generic, and professional. Where the relationship between theory and practice has often been at the center of the discussion [30], this model highlights a blind spot in this debate, where generic knowledge is defined as a separate form of knowledge, as opposed to professional knowledge. This model provides opportunities for analyzing the forms of knowledge that are expressed in the new teacher education and can be visualized as follows.

Figure 1 visualizes four forms of knowledge, based on the concepts of semantic gravity (SG) and semantic density (SD). These concepts may vary in strength $(+,-)$, and the different combinations give rise to four fundamentally different forms of knowledge in education [29, 31]:

(i) Theoretical (SG-, SD+), where basic achievements are characterized by relative context-independence and highly complex meanings

(ii) Practical (SG+, SD-), where legitimacy is linked to more context-dependent practices with simpler meanings

(iii) Generic (SG-, SD-), where the meaning of legitimate practices is relatively context-independent, with relatively simple meanings

(iv) Professional/vocation (SG+, SD+), where legitimacy is related to context-dependent practices that condense abstract and variable meaning

The concepts of semantic gravity (SG) and semantic density (SD) provide a guide to uncovering the organizational principles that underlie the various forms of knowledge that are present in the students' R\&D papers in the new Norwegian teacher education.

\section{Professional Knowledge and the Students' R\&D Papers in the New Norwegian Teacher Education}

The reform in the new Norwegian teacher education was implemented in 2017. As mentioned, this reform has taken crucial inspiration from Finland, with an extension to a fiveyear master's program, where students will acquire a new type of professional knowledge and gain specialized insight into a subject area (Master thesis). This expansion entails a renewal, with the development of a new type of researchbased professional knowledge, which will provide a new basis for teachers' professional practice. Research and research-based knowledge are given more weight, and students should gain more knowledge about relevant research and theory, and they should be able to design and conduct research themselves, using research methods, etc.

3.1. Background. In the third year, the students' bachelor thesis has been replaced with a research and development thesis (R\&D), a task that all students must pass to proceed to the master's program. The national guidelines for the new teacher education [32] state the following framework for students' R\&D papers:

In the third year of study, the student must write a research and development thesis (R\&D) in combination with one of the teaching subjects and pedagogy and student knowledge. The papers must be professionally oriented and linked to the field of practice or other aspects of the school's activities (p. 11-author's translation).

With this provision, the authorities have drawn up a very broad framework for students' $R \& D$ papers. What is clear is that this should be an independent research paper, where the purpose is to develop a new knowledge base for the practice of the profession. However, although the purpose of the new teacher education is to develop a new scientific and researchbased basis for the practice of the profession, a follow-up study shows that the students in that teacher education have little understanding of what the new research-based professional knowledge is about [33]. A recent study [12] concludes that many students perceive professional knowledge as a particularly practical and contextual form of knowledge. These contributions provide indications of some real problems in the new Norwegian teacher education.

While it was previously assumed that the production, recontextualization, and teaching of knowledge are what make education a distinct field of practice [34], pedagogical educational research with its strong focus on knowing has obscured what we can understand by knowledge in the professional education. In Norwegian teacher education, where progressive pedagogy has traditionally held a strong position [4], the tension between knowledge in the subject area and pedagogy is not a new date. However, in the new and reformed Norwegian teacher education, this tension has taken a new form, which especially is expressed in the question of what kind of knowledge should form the basis for teachers' professional practice.

3.2. Methods. To investigate these issues, related to the new knowledge base for teachers' professional practice, this paper will examine students' R\&D papers in the new Norwegian teacher education. This project includes all $R \& D$ papers submitted in the Spring of 2020 at Nord University, Nesna, a total of 25 papers (P1, P2, .., P25). The R\&D papers are stored in Inspera in Nord University, and after an approved application from Norwegian Center for Research Data (NSD), an extract of these R\&D papers has been made. These papers are well suited for uncovering the students' understanding of research-based professional knowledge, and we will draw attention to the students' perceptions of knowledge and the tension between knowledge in the subject area and pedagogical approaches.

This paper explores the types of knowledge that are expressed in the students' R\&D papers. To do this, we applied a semantic text analysis method [35], which provides opportunities for quantitative and qualitative content analyses of the students' papers [36]. The text analysis will be directed by the dimension semantics in Maton's theory, which emphasizes the concepts semantic gravity and 
semantic density. The content analysis, which aims to systematize the parts of the content that are relevant to the paper's research questions, was performed using a code form, referred to as the translation device (Tables 1 and 2). Using this form, key content elements were identified, and a systematic mapping of selected text quotes was carried out. The selected text quotes were interpreted in light of the concepts discussed. In order to gain insight into which meanings are central, the content elements were interpreted in a larger societal context, referred to as the semantic structure of the field of education. The qualitative analysis provided a basis for mapping the extent of different perceptions of professional knowledge, as they are expressed in the students' R\&D papers.

\section{Translation Device for Analyzing Student Papers}

To create a connection between theory and data, there is a need to develop a translation device suitable for analyzing students' R\&D papers in the new teacher education. This translation device is based on the LCT-dimension semantics and aims to analyze knowledge practices and provide insight into the principles that underlie these practices. As mentioned before, all practices include semantic gravity and semantic density, with varying degrees of semantic strength. These variations in the context-dependence and density of the sentences produce semantic changes, something Maton refers to as the semantic profile [28] (p. 17). These concepts show how different forms of knowledge interact, their semantic strength, and can provide insight into different forms of knowledge and knowledge building in students' R\&D papers. Inspired by Maton and Chen [37] (p. 44) and Maton and Duran [38], a translation device was developed, with an external language, which can create a connection between theory data, and that allows the coding of data.

While semantic gravity (SG) deals with the contextual dependency of meanings, the concept of semantic density (SD) sheds light on the internal references of meanings, their strength, and their capacity to create a strong system of meanings, related to complex systems of concepts, which will be central for the possibilities to shape an epistemic structure with an increasing degree of generality.

Tables 1 and 2 have a design that provides opportunities for a semantic analysis of students' understanding of professional knowledge, expressed by the knowledge practices that are articulated in students' $R \& D$ papers. The translation device makes it possible to systematically map data and provides opportunities to pass the empirical descriptions of the students' knowledge practices and relate data to concepts. More generally, the semantic analysis can uncover the principles that lie under the students' knowledge practices and identify which forms of knowledge are expressed in the students' R\&D papers. The concepts semantic gravity and semantic density are combined in the semantic analysis, making it possible to map how students create connections between various semantic levels, with the development of specific semantic profiles. These profiles, which establish relationships between theory and practice, cannot be seen regardless of the field, which reflects the nature of the knowledge practices in education. The meanings of the practices within a field depend on the semantic structure $[19,28,39]$, where the relational meanings of practices constitute the field. This means that the understanding of practices may be related to different meanings depending on the semantic structure that is made applicable. For example, Howard et al. have shown in several studies that for schoolteachers in Australia, the meanings of words such as "experience," "practice," and "knowledge" are linked to the subject area that they teach $[40,41]$. This means that the semantic analysis, with the use of the terms semantic gravity and semantic density, cannot be seen independently of the given field's semantic structure. In this paper, this structure is related to the paper's problem description, which gives a more in-depth description of the study object and its context here is referred to as the reform in the new Norwegian teacher education. This reform creates a situation of the emergence of conflicting perceptions of what we can understand with teachers' professional knowledge, with different interpretations about the relationship between theory and practice. The dispute crystallizes a tension between pedagogical approaches and approaches that emphasize knowledge in subject areas. The translation device provides several examples of how these contradictions are expressed at an empirical level, where the semantic analysis of the students' R\&D papers reveals "code clashes" between two fundamentally different approaches to what we can understand with professional knowledge in teacher education.

\section{Results}

The new Norwegian teacher education was initiated in 2017. In the third year of study, the bachelor thesis has been replaced by an R\&D thesis. According to the authorities' guidelines, this assignment must combine a special subject area and pedagogy, a combination that has been included in the curriculum at Nord University (Curriculum for MAGLU $1-7,2017$, p. 27) [42]. The goal of the students' R\&D papers is to develop a research-based and profession-oriented form of knowledge, which can strengthen the practice of the profession, and lay a foundation for the student's work on the Master's thesis [33]. This study includes 25 student papers submitted at Nord University, Nesna. The analysis of the students' papers was carried out based on the LCT-dimension semantics, with emphasis on the concepts of semantic gravity and semantic density [28].

The data were analyzed to identify the semantic profile of the student papers, as well as uncover the form of knowledge that informs the knowledge practices in the students' $R \& D$ papers. Although several different forms of knowledge are expressed in the students' R\&D papers, the analysis draws attention to the students' approach, the connection between theory and practice, what kind of theories or concepts are used to give meaning to practices. In line with what has previously been referred to as the field's semantic structure, a distinction is made between papers that emphasize specialized knowledge in the subject area and pedagogical approaches. The analysis of the students' paper revealed 
significant differences in what the students understand with teachers' professional knowledge. The analysis gave the following result presented in Figure 2.

The semantic analysis shows that the students' $R \& D$ papers are characterized by two different forms of knowledge, here categorized as generic knowledge (68\%) and professional knowledge (32\%). The analysis of student papers reveals two different semantic profiles and shows two very different versions of what can be understood as legitimate forms of professional knowledge in teacher education. Further analysis shows several differences in students' perceptions of legitimate forms of knowledge in teacher education.

Table 3 provides an overview of students' understanding of legitimate forms of knowledge in teacher education, expressed in their student papers, with knowledge practices governed by quite different forms of knowledge: generic knowledge (SG-, SD-) and professional knowledge (SG+, SG+). The students' papers that are regulated by generic knowledge are characterized by a combination of practices with a relatively weak context dependence, with relatively simple meanings. Although academic concepts apply, the meanings of these concepts are related to learning and the learners, not to a relational system of abstract concepts. The concepts and perspectives that are used nevertheless have a context-transcend character, not in the form of density, but by being linked to pedagogical learning processes, which can be applied in a homogeneous way across the school's subject areas, and in a broader sense of all forms of learning in and outside education. Students' papers based on generic pedagogical approaches typically focus on learning, on social or mental factors, and how such factors affect attitudes, thinking, or practices in education. "Knowledge" is typically perceived here as something that exists in people's heads or appears as a result of social processes. For example, several of the papers included in this study are based on the term "motivation," which is believed to be crucial for pupils' learning in school. In one paper (P12), the student takes as a starting point that the interest in science is declining in Norwegian schools and investigates on this basis whether inquiry-based learning methods can increase the motivation to learn science in school. In the paper, the student concludes as follows: "The inner motivation is closely linked to active participation and authenticity in the learning. The pupil's answers can be interpreted to mean that being able to decide, to a certain extent, what one wants to explore in class is very motivating." In another student paper (P11), which examines inquiry-based learning in science outside the classroom, the student concludes as follows: "What I have come up with in the 1st-grade class where I did my research, most of the pupils enjoyed working with inquiry-based methods outside the classroom." The third paper in social sciences examines whether the use of the local community can increase pupils' motivation for learning. In this paper (P15), based on a survey among teachers, the following conclusion is drawn: "teachers agree that proximity and security are factors that can create motivation for pupils. At the same time, they agree that it can be motivating for the pupils to be active and use their senses in their local environment." All the cited student papers have in common that they focus on motivation, based on pedagogical approaches. Motivation is not insignificant in education, but it is also a factor that focuses on social and mental conditions, where knowledge and knowledge building in the subject area are not considered. When specialized knowledge in the subject area is absent, the data in these student papers are interpreted by presenting pupils' and teachers' experiencebased and subjective assessments of student-centered learning methods in different subject areas. The social "code" already possessed by pupils and teachers is highlighted as a key to success, without any kind of connection to the subject's specialized knowledge and the principles underlying these knowledge practices.

The students' papers that are regulated by professional knowledge (SG+, $\mathrm{SD}+$ ) are characterized by a different type of semantic profile. These papers are relatively context-dependent $(\mathrm{SG}+)$ and linked to concepts in the subject area with abstract and complex meanings (SD+). In other words, in these papers, specialized knowledge is applied, not only by subject concepts that have a high degree of density but also by shaping the practices in the given context. Among the students' papers that are included in the study, there is, for example, a paper that examines the use of "maps" in school, a term the student describes in the following way: "Maps are used as a graphic representation of how our world is and has been... Being able to display data visually, and convey locally related information, is important not only from a professional but also a didactic perspective" (P14). Geographical maps are a term that encompasses many and complex meanings, which relate to an abstract concept system; at the same time, they are a concept that can help shape teaching in the classroom. In another paper, we also find a similar striking example of the teacher's professional knowledge: "By looking at the periodic table, explaining what it is, opportunities it offers and indicating the importance of this, both for researchers and pupils, and ways in which it can be taught, I have examined the challenges and opportunities that exist" (P24). The periodic table is a term that encompasses many and complex meanings, which are part of a complex relational conceptual system, with a strong density. The statement about the periodic table and how this concept can be involved in practices demonstrates why specialized knowledge in the subject area is so central to the teachers' professional knowledge base. By connecting concepts taken from the subject area to practices, the concepts become more context-sensitive and form their own complex meanings, resulting in neither theoretical knowledge nor practical knowledge but form organizational principles of their own for the knowledge practices of the profession.

\section{Discussion}

The reform of Norwegian teacher education introduces a new concept of knowledge in education, with emphasis on research-based knowledge, which will form the basis for future teachers' professional practice. Although researchbased knowledge appears to be a key concept in the new teacher education, the concept of knowledge is defined in an 


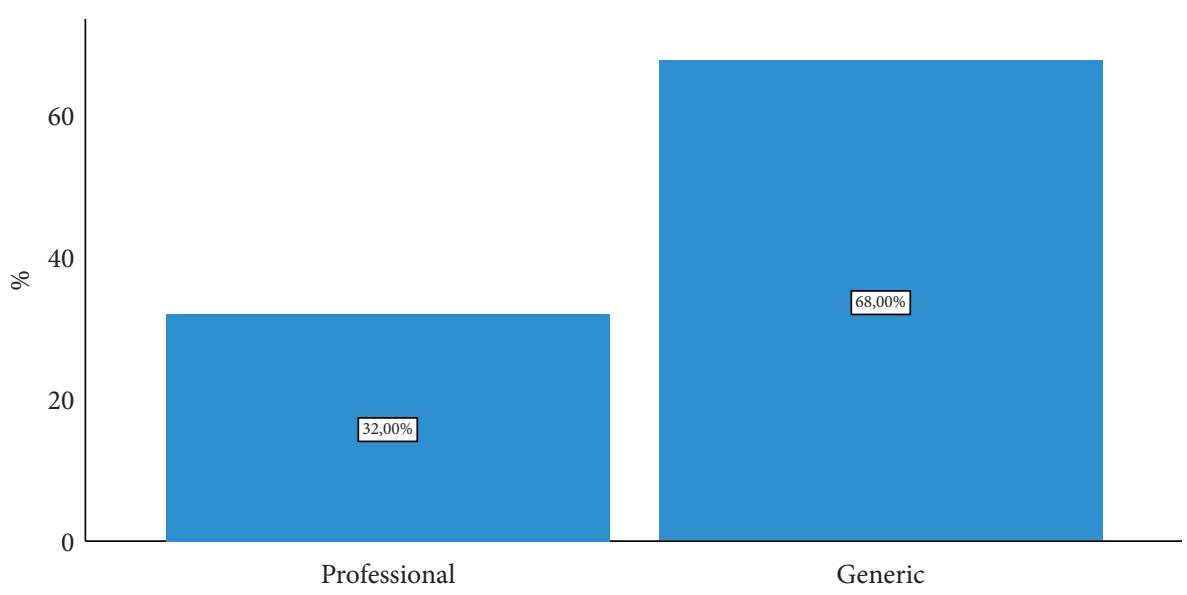

FIGURE 2: Forms of knowledge in students' R\&D papers.

TABLE 3: Students' perceptions of legitimate forms of knowledge in teacher education.

\begin{tabular}{|c|c|c|}
\hline \multirow{2}{*}{$\begin{array}{l}\text { General } \\
\text { characteristics }\end{array}$} & \multicolumn{2}{|l|}{ Knowledge } \\
\hline & $\begin{array}{l}\text { Generic knowledge (SG-, SD-) } \\
\text { Pedagogical approaches }\end{array}$ & $\begin{array}{l}\text { Professional knowledge (SG+, SG+) } \\
\text { Knowledge in the subject area }\end{array}$ \\
\hline Practice and theory & $\begin{array}{c}\text { Practices are informed by recontextualized concepts derived from } \\
\text { pedagogical learning theories }\end{array}$ & $\begin{array}{l}\text { Practices are informed by specialized } \\
\text { knowledge, retrieved from subject areas }\end{array}$ \\
\hline $\begin{array}{l}\text { Practice and } \\
\text { learning }\end{array}$ & $\begin{array}{c}\text { Practices are understood as learning, which takes place using } \\
\text { student active learning methods }\end{array}$ & $\begin{array}{c}\text { Practices are understood as active acquisition of } \\
\text { the subject's knowledge }\end{array}$ \\
\hline $\begin{array}{l}\text { Reflections and } \\
\text { experience }\end{array}$ & Subjective and social reflections of practice experiences & Epistemic reflections of practic \\
\hline $\begin{array}{l}\text { Experience and } \\
\text { knowledge }\end{array}$ & $\begin{array}{c}\text { Experiences and the creation of meanings are important sources of } \\
\text { knowledge }\end{array}$ & $\begin{array}{l}\text { Experiences should be linked to the special } \\
\text { knowledge in the subject area }\end{array}$ \\
\hline $\begin{array}{l}\text { Learning and } \\
\text { knowledge }\end{array}$ & $\begin{array}{l}\text { Learning is seen as a process, which can be performed without } \\
\text { regard to specialized knowledge in the subject area }\end{array}$ & $\begin{array}{l}\text { Learning and teaching is associated with } \\
\text { specialized knowledge in the subject area }\end{array}$ \\
\hline
\end{tabular}

expanded way, with emphasis on skills and competence $[4,7,18]$. This broad and partly unclear concept of knowledge is part of the new Norwegian teacher education and creates a conflicting space, where different definitions of professional knowledge stand against each other. In this paper, we have taken as our starting point a semantic definition of professional knowledge, one whose definition has been used in several other LCT research contributions $[29,31]$. Professional knowledge is here regulated by organizational principles, which combines relative context dependence (SG+) with concepts and theories with abstract and complex meanings (SD-). This definition makes it possible to distinguish between different forms of knowledge in education (e.g., between generic knowledge and professional knowledge) (Figure 1). Nevertheless, the situation in the new Norwegian teacher education calls for a need to clarify what is meant by teachers' professional knowledge.

As the analysis shows, the students' papers have two quite different semantic profiles, which give two quite different answers to what the students understand the teachers' professional knowledge. The semantic "codes" that regulate generic knowledge (SG-, SD-) and professional knowledge $(\mathrm{SG}+, \mathrm{SD}+)$ are different and indicate quite different platforms for the teaching profession, with very different opportunities for developing pupils' knowledge in the subject area. Professional knowledge is characterized by specialized knowledge in subject areas, a form of knowledge that is related to an abstract system of subject concepts which shapes practices in education. Professional knowledge includes a stronger density (SD+), with opportunities to integrate concepts with the development of an increasingly strong degree of generality. When the subject's concepts are linked to practices in education, it creates a basis for "conceptual progression" [25] and "cumulative knowledge building" [28], where students can develop knowledge, which can be transferred to new contexts. Winch investigated how specialized knowledge in a subject area is a part of it and shapes practices and how these forms of knowledge can work together and contribute to cumulative knowledge building, will require research-based knowledge, which will be essential for teachers' professional knowledge [43]. Weak semantic density (SD-) means that concepts are more loosely integrated and segmented. Generic knowledge in teacher education means that the concepts are not related to the knowledge in the subject area, where the teaching profession knowledge base is limited to learning and learning processes. According to Shay [29] (p. 576), generic knowledge can be defined as a "recontextualization of pseudopractical knowledge," because it is not rooted in specific practices. This is a form of "know-how" knowledge about learning, also referred to as a specialized action competence $[13,14]$, that can be applied in many contexts 
because it includes concepts and perspectives that are not linked to specific practices but can be applied to all practices, which involve learning and development. Because pedagogical approaches are decoupled from knowledge in the subject area and have a strong focus on learning and learners, experience-based and student-centered activities are emphasized, which leads to a state where ways of knowing are confused with knowledge in education. Because pedagogical approaches are not linked to theories and concepts in the subject area, approaches within this category provide limited opportunities to build knowledge in the subject area, where pupils are at risk of acquiring local and fragmented forms of knowledge, which can lead to segmentalism.

With this generic pedagogical version, professional knowledge in teacher education is reduced to ways of knowing, where professional knowledge is something that arises in specific sociocultural processes or is constructed by learners [19]. In this generic version, research and researchbased knowledge become a question of learning and of studies of social and mental factors that can promote learning processes in education. Research-related pedagogical approaches, which in the students' papers, for example, can deal with investigations of student-centered learning methods, social competence, relationships, learning environment, collaboration, or motivation, does not consider the subject's forms of knowledge, or whether the school pupils acquire knowledge in the subject area. The knowledge the students in the teacher education acquire, and which is to form the basis for their professional practice, is a form of knowers' specialization-how pupils in schools learn ways of knowing, with no connections to the subject area's specialized form of knowledge. The result is a form of "learnification" [44], with learning processes without subject concepts.

A key purpose of the reform in the new Norwegian teacher education is to place a stronger emphasis on research-based knowledge, as a new basis for teachers' professional practice. This paper reveals two different versions of what students understand by the concept of professional knowledge in teacher education. On the one hand, there is a pedagogical version, and on the other hand, there is one version that is based on the subject area, which examines practices in the classroom in relation to the subject area's form of knowledge. Of the two versions, only the latter provides epistemic access [24], which opens for cumulative forms of knowledge building in the classroom, with practices where pupils can acquire a deeper understanding of the subject's specialized knowledge. This latest version, which is expressed in a smaller part of the papers in this study, is contributions that provide answers to how research-based knowledge can provide a new basis for teachers' professional practices in education.

These contributions show why professional knowledge also is "powerful knowledge" [45], something which presupposes that the students have access to theoretical knowledge in education [1], as this is expressed in the subjects' concepts and theories. When the teacher's professional knowledge is detached from the subjects' concepts, the result will be "learnification"-an overemphasis on pedagogy and the learner at the expense of what is taught [44]. The one-sided emphasis on pedagogical "know-how" knowledge about learning has created confusion and uncertainty among Norwegian teacher students about what is meant by research-based professional knowledge and how they can understand the relationship between theory and practice in their profession $[4,33]$. This problem is related to the old contradiction between progressivism and epistemic knowledge in education. However, this contradiction can be overcome by drawing attention to the knowledge-based nature of teachers' professional work [16], especially related to how the subjects' specialized knowledge is involved in teachers' knowledge practices in the classroom [23, 37].

\section{Conclusions}

The debate about the teaching profession's knowledge base has traditionally been marked by a polarization between practical and theoretical knowledge [30]. With the neoliberal education reforms of today, with the introduction of a new and expanded concept of knowledge in education, which emphasizes skills and competence, this picture has become more complicated $[16,31]$. In the new Norwegian teacher education, a dispute has arisen about what kind of knowledge should form the basis for professional practices and what we can understand by professional knowledge in teacher's education. The analysis of the students' R\&D papers shows that the two versions stand against each other. In the progressive pedagogical version, knowledge is reduced to ways of knowing [19] by focusing on social and mental states and by ignoring the subject area's form of knowledge. In this way, professional knowledge is understood as a generic form of knowledge about learning in education, which provides a basis for teaching practices, which can be applied in a homogeneous way across different subject areas in education. This paper rejects this version and argues that the teachers' professional knowledge is inextricably linked to the subject area's form of knowledge. Professional knowledge in teacher education is a form of knowledge that is created through the integration of theory and practice, where the subject area's specialized form of knowledge informs the practices and develops the profession's knowledge base.

This paper is based on a study that sheds light on what the students in the new Norwegian teacher education understand with the teacher's professional knowledge, including what is perceived as legitimate knowledge, and how research-based knowledge can develop the profession's knowledge base. Nevertheless, more research is needed to fully understand the relationship between the subject area's knowledge and professional knowledge in teacher education. This study includes students' papers that have been submitted in several different subject areas in teacher education, and it shows that didactics in many papers is understood as pedagogical approaches, which are detached from the subjects' forms of knowledge. Other key topics will include questions about how research-based knowledge can strengthen teachers' knowledge practices in subject areas, in what way this research-based knowledge can contribute to 
knowledge building, progression, better learning outcomes, and student's achievement. This case study is based on students' papers, which have been directed by national guidelines, in a context where progressive pedagogy holds a strong position. The interpretations of the findings in this study will have limitations, related to what kind of information has been given to the students, the possibilities for differences between the institutions, the possibility of biased views, and weak supervision competence of individual teachers.

In conclusion, knowledge matters in teachers' education. The subject area's form of knowledge has effects, which shape distinct practices in the classroom. How specialized knowledge in the subject area affects teaching practices in the classroom and how these practices bring different forms of knowledge together are key questions for a new teacher education, which can help strengthen the knowledge base for teachers' professional practices in school.

\section{Data Availability}

This project includes all R\&D papers submitted in the Spring of 2020 at Nord University, Nesna-a total of 25 papers. This paper examines the types of knowledge that are expressed in the students' $R \& D$ papers. The $R \& D$ papers are stored in Inspera in Nord University, and after an approved application from Norwegian Center for Research Data (NSD), an extract of these R\&D papers has been made.

\section{Conflicts of Interest}

The authors declare that there are no conflicts of interest regarding the publication of this paper.

\section{References}

[1] L. Wheelahan, Why Knowledge Matters in Curriculum: A Social Realist Argument, Routledge, London, UK, 2010.

[2] H. Lauder, M. Young, H. Daniels, M. Balarin, and J. Lowe, Educating for the Knowledge Economy?: Critical Perspectives, Routledge, London, UK, 2012.

[3] N. Stehr, Knowledge Societies, Sage, London, UK, 1994.

[4] E. Elstad, Lorerutdanning I Nordiske Land, Universitetsforlaget, Oslo, Norway, 2020.

[5] H. Bergesen, Kampen Om Kunnskapsskolen, Universitetsforl, Oslo, Norway, 2006.

[6] A. Benavot and H. D. Meyer, PISA, Power, and Policy: The Emergence of Global Educational Governance, Symposium Books, Oxford, UK, 2013.

[7] E. Bratland, D. Siemieniecka, and B. "Siemieniecki, Knowledge, ICT and Education: A Variety of Perspectives, Wydawnictwo Adam Marszałek, Toruń, Poland, 2016.

[8] S. Østerud, Utdanning for Informasjonssamfunnet: Den Tredje Vei [Education for the Information Society: The Third Way], Universitetsforl, Oslo, Norway, 2004.

[9] U. Blossing, G. Imsen, and L. Moos, "Progressive education and new governance in Denmark, Norway, and Sweden," The Nordic Education Model: "A School for All" Encounters NeoLiberal Policy, Springer, Dordrecht, Netheralands, pp. 133154, 2014.
[10] P. Haug, "Norsk lærarutdanning-kva har skjedd med pedagogikkfaget?" Norsk Pedagogisk Tidskrift, vol. 92, no. 6, pp. 486-492, 2008.

[11] G. Imsen and M. R. Ramberg, "Fra progressivisme til tradisjonalisme i den norske grunnskolen?” Sosiologi I Dag, vol. 44, no. 4, pp. 10-35, 2014.

[12] E. Bratland and M. El Ghami, "The icarus effect rephrased: range of semantic gravity and forms of knowledge in new Norwegian teacher education," Education Research International, vol. 2021, Article ID 9982339, 7 pages, 2021.

[13] M. B. Postholm, "The complementarity of formative intervention research, action research and action learning," $E d$ ucational Research, vol. 62, no. 3, 2020.

[14] R. Säljö, Ø. Gilje, and I. C. Goveia, Loring: en introduksjon til perspektiver og metaforer, Cappelen Damm akademisk, Oslo, Norway, 2016.

[15] R. K. Sawyer, The Cambridge Handbook of the Learning Sciences, Cambridge University Press, Cambridge, UK, 2006.

[16] M. Young and J. Muller, "Towards the sociology of professional knowledge," in Knowledge, Expertise and the Professions, M. Young and J. Muller, Eds., pp. 3-17, Routledge, London, UK, 1 edition, 2014.

[17] K. Maton and R. Moore, Social Realism, Knowledge and the Sociology of Education: Coalitions of the Mind, Continuum, London, UK, 2010.

[18] M. F. D. Young, Bringing Knowledge Back in: From Social Constructivism to Social Realism in the Sociology of Education, Routledge, London, UK, 2008.

[19] K. Maton, Knowledge and Knowers: Towards a Realist Sociology of Education, Routledge, New York, NY, USA, 2014.

[20] P. Freebody, K. Maton, and J. Martin, "Talk, text, and knowledge in cumulative, Integrated learning: a response to intellectual challenge," Australian Journal of Language and Literacy, vol. 31, pp. 188-201, 2008.

[21] J. H. Van Driel and A. Berry, "Teacher professional development focusing on pedagogical content knowledge," Educational Researcher, vol. 41, no. 1, pp. 26-28, 2012.

[22] K. Maton, S. Hood, and S. Shay, Knowledge-building: Educational Studies in Legitimation Code Theory, Routledge, Taylor \& Francis Group, New York, NY, USA, 2016.

[23] K. Maton and R. Chen, "Specialization codes: knowledge, knowers and student succes," in Accessing Academic Discourse: Systemic Functional Linguistics and Legitimation Code Theory, J. R. Martin, Y. J. Doran, and K. Maton, Eds., Routledge, London, UK, 2020.

[24] S. Shay, "Curriculum in higher education: beyond false choices," in Thinking about Higher Education, P. Gibbs and R. Barnett, Eds., pp. 139-155, Springer International Publishing, Cham, Switzerland, 1st edition, 2014.

[25] E. Rata, "A pedagogy of conceptual progression and the case for academic knowledge," British Educational Research Journal, vol. 42, no. 1, pp. 168-184, 2016.

[26] K. Ananiadou and M. Claro, "21st century skills and competences for new millennium learners in OECD countries," pp. 1-33, 2009, OECD Education Working Papers(41).

[27] G. McPhail and E. Rata, "Comparing curriculum types: "powerful knowledge" and "21st century learning"," New Zealand Journal of Educational Studies, vol. 51, no. 1, pp. 53-68, 2016.

[28] M. Maton, "Building knowledge about knowledge-building," in Knowledge-building: Educational Studies in Legitimation Code Theory, K. Maton, S. Hood, and S. Shay, Eds., pp. 1-23, Routledge, Taylor \& Francis Group, London, UK, 2016. 
[29] S. Shay, "Conceptualizing curriculum differentiation in higher education: a sociology of knowledge point of view," British Journal of Sociology of Education, vol. 34, no. 4, pp. 563-582, 2013.

[30] G. Squires, "Art, science and the professions," Studies in Higher Education, vol. 30, no. 2, pp. 127-136, 2005.

[31] E. Bratland, "Professional knowledge in education: what kind of organizational principles are behind the knowledge practices, and what are the conditions for developing this knowledge?" Prolemy Profesjonlogii, vol. 167-177, 2017.

[32] National Council for Teacher Education, Nasjonale Retningslinjer for Grunnskoleloererutdanningen, 2016 Grunnskoleloererutdanningen, UHR-Lærerutdanning, Oslo, Norway, 2016, https://www.uhr.no/_f/p1/ibda59a76-750c-43f2-b95aa7690820ccf4/revidert-171018-nasjonale-retningslinjer-forgrunnskolelarerutdanning-trinn-1-7_fin.pdf.

[33] H. Afdal and F. R. Bjordal, "5-årig grunnskoleloererutdanning på masternivå-ny og utfordrende: Et følgeforskningsprosjekt ved Høgskolen $i$ Østfold: [5-year primary school teacher education at master's level-new and challenging: follow-up research project at the University College in Østfold]": Delrapport IUniversitetet I Sørøst-Norge, Notodden, Norway, 2019.

[34] B. Bernstein, Pedagogy, Symbolic Control, and Identity: Theory, Research, Critique, Rowman \& Littlefield, Lanham, ML, USA, 2000.

[35] Ø. Bratberg, Tekstanalyse for Samfunnsvitere [Text Analysis for Social Scientists, Cappelen Damm akademisk, Oslo, Norway, Third edition, 2021.

[36] K. Krippendorff, Content analysis: An Introduction to its Methodology, SAGE, Los Angeles, CF, USA, Fourth edition, 2019.

[37] K. Maton and R. Chen, "LCT in qualitative research: creating a translation device for studying constructivist pedagogy," in Knowldege-biulding. Educational Studies in Legitmation Code Theory, K. Maton, S. Hood, and S. Shay, Eds., pp. 45-66, Routledge, London, UK, 2016.

[38] K. Maton, Y. J. Doran, and Y. J. Doran, "Semantic density: a translation device for revealing complexity of knowledge practices in discourse, part 1-wording," Onomázein Revista de lingüística, filología y traducción, vol. SFL, no. 1, pp. 46-76, 2017.

[39] K. Maton, L. Carvalho, and A. Dong, "LCT in praxis: creating an e- learning environment for informal learning of principled knowledge," in Knowledge-building. Educational Studies in Legitimaton Code Theory, K. Maton, S. Hood, and S. Shay, Eds., pp. 90-110, Routledge, London, UK, 2016.

[40] S. Howard and K. Maton, "Theorising knowledge practices: a missing piece of the educational technology puzzle," Research in Learning Technology, vol. 19, no. 3, pp. 191-206, 2011.

[41] S. K. Howard, A. Chan, and P. Caputi, "More than beliefs: subject areas and teachers' integration of laptops in secondary teaching," British Journal of Educational Technology, vol. 46, no. 2, pp. 360-369, 2015.

[42] Studieplan, Grunnskoleloererutdanning 1.-7. Trinn-5-årig Master, Nord universitet, Bodo, Norway, 2017.

[43] C. Winch, "Know-how and knowledge in the professional curriculum," in Knowledge, Expertise and the Professions, M. Young and J. Muller, Eds., pp. 57-70, Routledge, London, UK, 2014.

[44] G. Biesta, "Giving teaching back to education: responding to the disappearance of the teacher," Phenomenology and Practice, vol. 6, no. 2, pp. 35-49, 2012.

[45] M. Young and J. Muller, "On the powers of powerful knowledge," Review of Education, vol. 1, no. 3, pp. 229-250, 2013. 